\title{
DEFENCE BUDGET TRANSPARENCY ON THE INTERNET
}

\section{Kate STARKEY and Andri van MENS}

\begin{abstract}
A $\mathrm{s}$ the Balkans and the international community look back on more than ten years of unrest in South-Eastern Europe (SEE), many are striving to find solutions to the region's problems. One measure being contemplated is regional defence budget transparency. It is thought that if the SEE states can come to a common agreement on sharing defence expenditure information, a mutual understanding and an enhanced dialogue on security matters can be achieved. Better understanding of each others' concerns in turn would lead to increasing confidence between states, reducing military tensions among neighbours. With respect to the development of democratic institutions, transparency can furthermore enhance public debate and contribute to the efficiency of the democratic processes.

While matters of secrecy and transparency in public affairs have traditionally been of public concern, ${ }^{1}$ today's modern technology has the potential to elevate the issue to a higher level. As Joseph Stiglitz notes:

The end of the Cold War has provided us the opportunity [...] to re-examine the role of secrecy and openness. At the same time, new technologies have provided mechanisms through which information can be more effectively shared between government and those governed. ${ }^{2}$
\end{abstract}

In this paper, after focusing on some issues of democracy, defence budget transparency and what they mean for security, we assess the availability of defence expenditure figures on the Internet for some European and North American countries. This is done in order to come to better understand what is available at the moment, to find out what more can be done with respect to defence budget transparency on the Internet, and ultimately to see in what way this tool can become useful in enhancing regional military cooperation and understanding in SEE. 


\section{Issues of Democracy, Defence Budget Transparency, and Security}

A fundamental relationship exists between defence budget transparency and peace and security in a region. It supports the notion that democracies avoid using military means when solving disputes. The dynamic is as much internal to each state as it is external on a larger regional scale, as transparency allows for better national and international control over the government decision-making process.

Transparency in governance is a prerequisite for a sound democratic system. If democracy is a political system built on social dialogue where open discussion is fundamental to the decision-making process, then openness of information has to be its pillar. As such, transparency, underpinning the right to know, is a basic public right in a democratic society. Moreover, only transparency can lead to well-informed rational decisions. As Joseph Stiglitz further states: "It is only [...] through informed discussion of the policies being pursued [...] that effective governance can be exercised." The availability of information as well as the openness of the decisionmaking process enables experts to participate in the public debate. Basing their assumptions on accurate information, these experts can assess a situation, evaluate the alternatives, set the priorities, and recommend the best public policy available given its projected outcome. The accuracy of their projections can be expected to be proportional to the information available since transparency is key to correct policy evaluation. In fact, openness of information creates a realistic opportunity for timely policy adjustments when forecasting errors occur. Thus democracy relies on openness of information as well as public and expert control. While public debate insures that people are talking, the availability of information guarantees that everyone is talking about the same thing. Democracy is a system of checks and balances, of consideration and reconsideration: it is a decision-making process, a process that is fundamental to the sound planning of public affairs.

The planning, programming, and budgeting system (PPBS) used in the United States for defence budget development and presently being introduced in the Bulgarian Ministry of Defence, relies on a defence programming cycle of this nature. ${ }^{3}$ A typical PPBS cycle consists of an initial planning phase, in which the security environment, as well as national interests and threats are analysed in order to determine the tasks, the composition, and the structure of the armed forces. Considering these imperatives, programs are developed. The program, a form of business plan, identifies the concrete objectives to be met. It is a crucial link in the cycle as it works to relate the identified objectives to the financial resources. In this way, PPBS parts with the practice of allocating resources according to the stated needs and instead looks to plan and program according to given and forecasted budgetary constraints. Hence, it is important that the programs are developed on a priority basis, where the most immediate needs for the armed forces are met. Risk assessments dealing with the 
consequences of not meeting a given objective can be used for setting the priorities. Completing the cycle in the end is a performance measurement phase during which the ministry in particular and society as a whole can determine to what extent the objectives have been met at the end of the year. An efficient distribution of resources can thus be achieved:

[B]eing introduced with the aim to increase effectiveness of defence resource management, defence programming is an important element of civil-military relations and, potentially, an important driving force for the establishment of effective democratic control over the armed forces. ${ }^{4}$

The different stages of the cycle provide an opportunity for, and are indeed submitted to, public scrutiny through public discussion, expert involvement and parliamentary ratification. In relation to defence policy and military expenditures in South Eastern Europe (SEE), public as well as expert influence could elevate the decision-making process beyond emotional value-loaded historical considerations. ${ }^{5}$ As well, accurate threat assessments could in turn lead to the restructuring of armed forces and defence expenditure reductions. The money saved could potentially be used in the socioeconomic sphere, which would make sense security-wise, as economic development would undoubtedly lead to greater social stability. On the contrary, excessive defence expenditures might lead to greater unrest. As Paul George points out:

We know from past experience that excessive military expenditure can increase economic insecurity by reducing the availability of resources that could be invested more beneficially in other sectors. Economic insecurity can then become a potential source of internal instability thereby leading to a vicious circle in which further security expenditure is required as governments strive desperately to contain unrest. Nor do internally generated military expenditure increases easily remain confined to a single state. As a country increases its defence spending to contain domestic instability, alarm bells ring in neighbouring countries and regional military spending levels tend to rise in response. Inevitably, this broadens the negative impact of increases in the unproductive use of scarce resources and reduces regional opportunities for investment in urgent social sector priorities. It also perpetuates the cycle of instability and decreases the overall security environment. ${ }^{6}$

Of course, military cutbacks in one country are contingent on similar cutbacks in neighbouring countries, and it thus comes down to knowing what the others' defence priorities are.

Diplomatically, defence budget transparency based on planning and programming is an important confidence-building tool between neighbouring countries. ${ }^{7}$ 
Transparency in the budgeting process, part of which is concerned with risk assessments and evaluations of the security context, enables a country to indirectly influence another's defence decision-making process. As such, it provides one with the opportunity to correct another's strategic concept (possibly by clarifying its own), and to ask specific questions related to the defence policy (procurement, exercises, restructuring, etc.) "[As] the general lack of accountability and transparency in defence budgeting can [...] feed concerns about the size, capabilities and intentions of a country's armed forces", writes Paul George, "[g]reater transparency will draw attention to military spending and reduce the potential for uncertainty and misunderstanding that lead to conflict." ${ }^{8}$ In the end, it creates a greater feeling of security.

Overall, transparency facilitates control over defence spending, reducing the possibility of excessive expenditures. As a result, more money can be channelled to socio-economic development. In this way, transparency can both reduce militarism, in itself a conflict-enhancing factor, and moderate socio-economic tensions. In essence transparency leads to dialogue and well-informed, rational decisions.

\section{Defence Budget Transparency on the Internet}

Effective civil control over the government decision-making process depends both on transparency during the budgeting process and on transparency in terms of free access to the budget as it is voted by parliament. One is not distinct from the other. If experts are to participate in discussions, they need to be informed through access to previous budgets. More importantly, if foreign governments are to be informed, they would most likely want to have the same opportunity for comparison and will appreciate having access to the official defence expenditure figures and the nature of these expenditures. Modern technology provides governments and defence ministries access to such data through the Internet, a relatively quick and inexpensive research tool offering immediate results, provided the information is available.

The following report looks into the availability of the above-mentioned information. It was compiled to provide a baseline for measuring the progress with respect to budget transparency in the future. The results varied, from countries that presented very detailed and informative backgrounds on their military spending, to other countries that only provided a brief background and a couple of figures, if any.

The research was conducted by dividing the countries into three sections. This was mostly done with the intention of comparing countries of similar backgrounds with one another so that any discrepancies between countries as a whole would not be too large. The following sections were created for the purpose of comparative research: 
- South Eastern European countries (countries participating in the SouthEastern Defence Ministerial and the Multi-National Peace Force SouthEastern Europe /MPFSEE/, as well as Stability Pact members)

- Other Central and Eastern European countries

- Western European and North American countries

The findings come from the English versions of the countries' defence and finance ministries' websites (in some cases the general governmental site was consulted). Choosing the English language is a normative consideration, which should be kept in mind when reading this document. As a now widely recognized diplomatic language, our focus on the availability of English information seems nevertheless to be a legitimate choice, especially if one considers defence budget transparency as a diplomatic tool for avoiding armed conflict. One should not conclude however, that the lack of budgetary information on the English sites illustrates a lack of openness on the part of either the Ministry of Defence or the Ministry of Finance of the respective countries.

\section{Country Reports}

\section{South Eastern Europe (MPFSEE and Stability Pact members)}

\section{Albania}

None of the relevant Albanian institutions can be reached through the NATO-site, which lists all the NATO partner countries and links to important state institutions (i.e. Parliament, Head of State, Government, Ministry of Defence, Ministry of Foreign Affairs, and the Ministry of Finance). If such pages do exist however, then it should be noted that they are hard to find as we unsuccessfully searched the Internet with some of the more frequently used search engines.

\section{Bosnia and Herzegovina}

As in the case of Albania, there appears to be no relevant information for Bosnia and Herzegovina available on the Internet.

\section{Bulgaria}

Defence budget information for Bulgaria is scarce on the Internet. The Ministry of Finance at http://www.minfin.government.bg/www/index.html and the Government at http://www.government.bg barely mention defence, let alone defence expenditures. The Ministry of Defence at http://www.md.government.bg has some indirect budget information in its executive summary of the Plan for Organizational Development of 
the Ministry of Defence by the Year 2004 as it covers capabilities restructuring, infrastructure restructuring and defence budget restructuring without providing explicit expenditure figures. There seems to be progress however as the Bulgarian Government published, while we were finalizing the current report, the English version of the Annual Report on the State of National Security of the Republic of Bulgaria in 1999 (Sofia, June 2000) at http://www.government.bg/eng/oficial_docs /index.html. In five of its appendixes it contains information on defense and security related expenses in terms of functions and operations. The report points out that 656.9 million levs equal to $2.88 \%$ of the GDP or $6.44 \%$ of the state budget were spent on defence. Of that amount 580.6 levs, or $2.55 \%$ of the GDP, made up the budget of the Ministry of Defence. The report gives a cross-section of the other defence and security related expenses, as well as their distribution in terms of 'costs', 'wages, social security, etc.' and 'investments.' It is expected that detailed distribution of the defence budget will be made available through the Internet with the publication of the first Annual Report on the State of Defence and the Armed Forces of the Republic of Bulgaria.

\section{Croatia}

Croatia has very little budgetary information on the Internet, especially pertaining to the defence budget. The English version of the web page of the Government of Croatia can be found at http://www.vlada.hr/english/contents.html. While there is no budget information here, there are links to the different ministries. The Ministry of Defence is at http://tomislav.morh.tel.hr, but the site is under construction and has been for a while. Thus the only hint of any military budget information is found on the site of the Ministry of Finance at http://www.mfin.hr/index_eng.htm. This site presents very informative monthly statistical reviews prepared by the Macroeconomic Analysis and Forecasting Department of the ministry and going back to 1995. The latest one, the June 2000 issue (no. 56), compiles figures concerning the countries defence expenditures. Table $3 \mathrm{~A}$ gives the Budgetary Central Government Expenditures by Function. The table shows expenditures for Defence Affairs and Services have gone down from 6990659 Croatian crowns (HRK) in 1997 to the planned 4786388 HRK for 2000. The share of the defence expenditures in the State Budget has thus fallen from $20.3 \%$ in 1997 to $13.1 \%$ in 2000 .

\section{Former Yugoslav Republic of Macedonia}

The Republic of Macedonia has an English version of its Ministry of Defence website at http://www.morm.gov.mk/eng/mo_e.htm. While the defence budget cannot be found at this site, there is however a copy of the 1998 White Paper of the Defense of the Republic of Macedonia. Chapter 4 of this White Paper is dedicated entirely to 
budgetary issues. It contains information on the defence budgets for 1997 and 1998, on the further development of the defence budget, and a projection until 2008 of the defence budget. In 1997, the Ministry of Defence obtained \$60,171,406 US from the State budget or $2.23 \%$ of the GDP and $8.96 \%$ of the total budget. For 1998, similar figures were projected with a budget covering up to $8.56 \%$ of the total budget, equivalent to $2.27 \%$ of the GDP with the total amount of expenditures projected at $\$ 70,911,964$ US.

Between 1997 and 1998, 52.65\% (1997) and 54.75\% (1998) of the expenditures were general Defence Resources, and Personnel expenditures accounted for the other $47.35 \%$ and $45.25 \%$ respectively. Considering economic projection until 2002, the defence budget will grow to $\$ 99$ million US from the $\$ 70.91$ million US in 1998. At the same time however the participation of the defence budget in the GDP will fall from $2.27 \%$ in 1998 to $2.1 \%$ in 2002 . For the long-term, the defence budget is expected to grow to $\$ 102$ million US in 2008 .

\section{Greece}

The Greek governmental websites provide the outside observer with close to no information. Websites for the Ministry of Defence (http://www.mod.gr/english /index.htm), the Prime Minister's Office (http://www.primeminister.gr/index_en.htm) and the Ministry of Finances (divided in two sections: General Accounting Office at http://www.mof_glk.gr and General Secretary of Information Systems at http://www.gsis.gov.gr) do exist, but while some of them have English versions most of the relevant information is in Greek. The Ministry of Defence's web page has a link to the Greek White Paper, a link however, that is not active.

\section{Italy}

As in the Greek case, it is difficult for the outside observer to obtain any information pertaining to the Italian defence budget and the budgeting process as the official governmental websites are in Italian only (Ministry of Defence at http://www.difesa.it, the general government site at http://www.palazzochigi.it and the Ministry of Finance site at http://www.finanze.it).

\section{Romania}

Romania has two sources for defence budget information. The first can be found at the English language version of the Romanian Ministry of Defence's website at http://www.mil.logicnet.ro/old/0.htm. One section on this site deals in particular with the Defence Budget. It contains charts and graphs that show the evolution of the defence expenditure between 1990 and 1998. It appears these expenditures have 
fallen from \$1337.49 million US in 1990 to a little more than \$707 million US in 1997. In 1997, the Defence Budget accounted for $8.6 \%$ of the State budget and for some $1.77 \%$ of the GDP. In 1998 these figures were respectively $7.77 \%$ and $1.68 \%$. According to another chart, \$205,54 million US were spent on personnel expenditures in 1997, whereas $\$ 164,91$ million US were used for material expenditures and $\$ 163,87$ million US for Capital Investments.

The Romanian Ministry of Finance (http://www.mfinante.ro/menua.htm), in turn, has a monthly bulletin on its website with, amongst other things, the General Consolidated Budget, the State Budget and the accompanying charts. According to the figures concerning the State Budget of 1999, defence expenditures were to attain 8529,8 billion lei.

\section{Slovenia}

Slovenia's Ministry of Defence has an English version web-site at http://www.mors.si/mors/eng/index.htm. It covers subjects related to the Ministry of Defence through one link and the Slovenian Armed Forces through another. The Ministry of Defence section has no specific budget information. Only in passing can some information be obtained, notably in a document entitled Defence System covering aspects related to the national security, the defence system, and the military duty and service. The final sections of this document address the issue of planning: Defence Planning, Force Planning, Combat Readiness Planning and Operational Planning. Within these sections one can learn about the Slovenian planning process and methodology. Basic defence planning documents are thus adopted by parliament. Overall, three defence planning perspectives exist: a long-term plan covering 10 years or more, a medium-term plan covering 5 years and a short-term plan covering the fiscal year. In 1999, approximately US \$315 million, close to $1.5 \%$ of GDP, were spent on the implementation of these plans. Half of these financial resources covered the personnel costs (salaries, allowances and pensions), $22.3 \%$ of the money went to operational and maintenance costs, and $27.6 \%$ were intended for procurement. Only $0.1 \%$ was put aside for research and development.

The Armed Forces site, in turn, has more specific information about the make-up of the Slovenian armed forces. This information is found in the two documents entitled Force Composition and Armament.

\section{Turkey}

Turkey has two official sites related to military affairs: the Ministry of Defence at http://www.msb.gov.tr/bakan/bakan.htm and the Armed Forces at http: //www.tsk.mil.tr. While the Ministry of Defence site is only available in Turkish, the 
Armed Forces site also has an English language version, which unfortunately was out of order during the time of the reported research.

Although there is an English welcoming message on the home page, the Ministry of Finance site at http://www.maliye.gov.tr is in Turkish as well. Furthermore, it is still under construction.

\section{Other Central and Eastern European Countries}

\section{Belarus}

There appears to be no relevant information on the military budget of Belarus on the Internet as there are no Ministry of Defence or Ministry of Finance websites.

\section{Czech Republic}

The English versions of the Czech Ministry of Defence site at http://www.army.cz /english/index.htm, the Government site at http://www.vlada.cz/1250/eng/vlade /vlada_clenove.htm, and the Ministry of Finance site at http://www.mfcr.cz/scripts /hpe/default.asp have no specific military budget information. The government has some related information on their site in a document stating its policy. Chapter 4.4 covers subjects related to internal security, defence, and foreign policy. Taking into consideration its country's accession to NATO, the Czech government promises to adopt basic documents relating to the security, defence and military strategy. Moreover, it plans to "implement the commitment to increase military spending gradually by $0.1 \%$ annually to reach $2 \%$ of GDP by the year $2000 . "$

The Ministry of Finance provides some government financial statistics, including very basic expenditure figures. An analysis of these figures shows that Czech defence expenditures grew from 27,621 billion Czech Crowns (CZK) in 1994 to 33,936 billion CZK in 1999. Military capital expenditures went up from 5,945 billion CZK in 1995 to 9,415 billion CZK in 1999.

\section{Estonia}

The Estonian Ministry of Defence website is found at the address: http://www.mod.gov.ee where the only English link that exists provides the viewer with the Annual National Plan for implementation of the country's Membership Action Plan. Within the National Plan there is a brief paragraph addressing budgetary issues. This paragraph states that Estonia will increase its defence expenditures to $2 \%$ of the GDP by the year 2002, following the schedule of $1.6 \%$ in $2000,1.8 \%$ in 2001 , and $2 \%$ in 2002. This increase will focus on the establishment of an adequate military infrastructure in the sphere of military training and the quality of life of personnel. 
The Annual National Plan also states that "the overall objective of budget planning is to ensure complete transparency between the resources needed, political guidance and the planned goals."

\section{Hungary}

The Hungarian Ministry of Defence website is located at http://www.h-m.hu/mod. There is no specific budget information available. Within the Ministry's organizational chart, there is a section entitled MoD Budget Monitoring but no description follows. The Ministry of Finance website, which can be found through the governmental home page at http://www.meh.hu/default.htm, does not have any budgetary figures related to defence spending published in English on its site either.

\section{Latvia}

The Latvian Ministry of Defence website is located at http://www.mod.lv and although there is an icon for English viewing, the link is not in order. There is an English version of the Ministry of Finance website however (http://www.fm.gov.lv /05sak/05sak_a.htm), but it has no defence expenditure information.

\section{Lithuania}

The Lithuanian Ministry of Defence website is located at http://www.kam.lt/english. At this address there is a link to the 1999 White Paper. Within the White Paper there is a brief section on the budget. This section addresses such issues as the guidance for the defence budget, figures within the defence budget itself, military construction and procurement (extra-ordinary expenditures), and 'ordinary expenditures'. The Lithuanian government plans to increase defence spending through the following schedule: $0.8 \%$ of the GDP in $1997,1.3 \%$ in $1998,1.70 \%-1.75 \%$ in 2000 , and $1.95 \%-2.0 \%$ in the year 2001. In 1999 the defence budget was expected to be approximately 724 million Lt. (\$181 million US).

The above seems to be all the information available as the English language Ministry of Finance website at http://www.finmin.lt/fmhomeen.htm has budget information, but no military expenditure information.

\section{Moldova}

The English website address for the Moldavian Ministry of Defence is http://www.moldova.md/ro/government/oll/DEFENSE/index.htm. There are presently only four links on this page, none of which are related to budget information or expenditures. The Ministry of Finance website at http://www.moldova.md/en /government/index.html doesn't provide any defence budget information either. 


\section{Poland}

The Polish Ministry of Defence website is located at http://www.wp.mil.pl /glowna.html, but unfortunately the English language link is not active. This is also the case with the "Budget" link on the English Ministry of Finance website at http://www.mofnet.gov.pl/ministry/index.shtml.

\section{Russia}

Russia does not appear to have a Ministry of Defence website as this ministry is not mentioned on the special links page of the Russian Ministry of Foreign Affairs, where the Internet addresses of governmental departments and agencies are listed. On the other hand, the Russian federation is represented online with a Ministry of Finance website at http://www.minfin.ru. This site is in Russian only but has a few links to English pages. One of these links, entitled Information on Fiscal Sector presented by Economic Expert Group, leads to the Economic Expert Group of the Ministry of Finance of the Russian Federation website at http://www.eeg.ru. There is a table on this site giving the figures pertaining to the Federal Budget Execution. At the time of this research, it compared the budget execution for the months of January through May of 1999, with the budget execution for the same months of 2000. Defence expenditures for the first five months of 1999 were 32,5 billion Russian Roubles (RUR) or some $2.2 \%$ of GDP. During the same months this year, defence expenditures went up to 70,1 billion RUR, or some $2.9 \%$ of GDP.

\section{Slovakia}

The Slovakian Ministry of Defence website is located at http://www.mod.gov.sk but is presently unavailable. There is however some defence budget information available on the Ministry of Finance site at http://www.finance.gov.sk. Through the link State Budget, it is possible to obtain the state budget expenditures figures for 1999. Defence budget expenditures, 20,7 billion Slovak Crowns (SKK), are listed as public consumption of the state under current expenditures which, at 178,5 billion SKK, account for almost $92 \%$ of the total state expenditures (the rest being capital expenditures).

\section{Ukraine}

Ukraine appears to have a Ministry of Defence website at http://www. dod.niss.gov.ua, but when entrance is requested, the server seems not to be operating. The Ministry of Finance site is located at http://www.minfin.gov.ua. This site includes a button for an English version, but at the time of the research it was not activated. 


\section{Yugoslavia}

Yugoslavia does not appear to have a website for its Federal Ministry of Defence or its Ministry of Finance as such sites cannot be found with the help of elementary Internet surfing.

\section{Western Europe and North America}

\section{Canada}

The Canadian Department of National Defence website, at http://www.dnd.ca, provides basic budgetary information. The budget information is found within the policy section of the site, at http://www.dnd.ca/admpol/docs_e.htm, and provides 1999/2000 estimates in defence spending. Some of the details include elaboration on spending by maritime forces, land forces, air forces, as well as charts with a historical-comparative overview. Links are also provided to the Ministry of Finance website at http://www.fin.gc.ca, where full viewing of the 1998, 1999, and 2000 budgets is possible. For the 1999-2000 fiscal year, defence budget was apportioned as follows: $67.8 \%$ of the budget was allotted to personnel, operations and maintenance expenditures, $19.7 \%$ to capital expenditures, $5 \%$ to grants and contributions, and $7.1 \%$ to pensions and benefits plans. The Department of National Defence budget for 1999-2000 is $\$ 10.515$ billion (including revenues, but less transfers), up from $\$ 10.165$ billion the previous year. Defence as a share of Gross Domestic Product will continue to hold at just above the one percent threshold.

\section{Finland}

The Finnish Ministry of Defence website is located at http://www.vn.fi. Here, several English-language charts are available that outline defence spending in Finland. For example, in 1999, the share of defence spending from the total state expenditure was $4.82 \%$ and the 1999 budget proposes defence spending at 1.3\% of the GDP. The site also offers a chart detailing the division of defence spending in 1999. Of a total of 9,028 million FIM, 3490 million were spent on procurement, 3402 on payroll, 775 on other expenditures, 761 on real estate, 530 on the upkeep of transcripts, and 70 on peacekeeping. The Ministry of Finance website at http://www.vn.fi/vn/vm/english /mof.htm does not provide any additional information.

\section{France}

The French Ministry of Defence website (http://www.defense.gouv.fr) presents only the evolution of the defence budget in English. This evolution, which compares defence spending with countries such as Germany, the United States, and Great 
Britain as well as analysis through other comparative measures, is predominantly done in graph form with very little text. These charts can be found at the Internet address: http://www.defense.gouv.fr/sga/budget/indexb.htm. The Ministry goes into slightly more detail in French. One chart presents defence spending with respect to the state budget and the GDP, where defence spending steadily decreases as the two others gradually increase. The percentage of GDP spent on defence by the French government is also presented alongside that spent by the UK, the United States, and Germany. In 1997, France spent 2.93\% of its GDP on defence, and 2.71\% in 1999.

\section{Germany}

The German Ministry of Defence website (http://www.bundeswehr.de) is predominantly in German with some extracts in English. Within the English extracts there is a section entitled Bundeswehr Planning - Capabilities, Structures and Resources, in which some budgetary planning and expenditures are briefly outlined. The information provided stresses the German commitment to German unification, which "will absorb large amounts of funds for the foreseeable future." As a result, the defence budget has been placed at a lower priority than German unification. From the fiscal year of 1991, when the first all-German budget was introduced, until the fiscal year of 1994, defence expenditure was cut by approximately 6.4 billion DM (12 percent). The 1999 defence budget amounts to around 47.52 billion DM or approximately $10.2 \%$ of total federal expenditures.

\section{Great Britain}

The British Ministry of Defence website (http://www.mod.uk) has made a copy of its Annual Report of Defence Activity available in Adobe format. As well, it also has a copy of Expenditure Plans 99/00 to 00/01 and Expenditure Plans 00/01 to 01/02 in Adobe Format. Expenditure Plans 00/01 to 01/02 provides details in the area of the MoD's cash base with the total value of fixed assets at $£ 65$ billion. A detailed breakdown in cash plans studies the expenditures of the General Officer Commanding (Northern Ireland), Chief of Joint Operations, Chief of Defence Logistics, Defence Systems Procurement, Retirement pay, pensions and other payments to Service personnel, etc. The document also addresses the trends in cash spending. In 1999/2000, cash provision was valued at $£ 22,863$ million with spending at $2.6 \%$ of the GDP. The Expenditure Plans go into further detail with respect to Contingent Liabilities, Contingent Liabilities in Excess of $£ 100,000$, Appropriations in Aid, Public-Private Partnerships, Long Term Projects, Ship Procurement, Refitting, and Repair, and Exports of Defence Equipment.

Complete budget information, with the State Budgets from 1994 onwards, can be found at the Her Majesty's Treasury website at http://www.hm-treasury.gov.uk. 


\section{The Netherlands}

The English version of the Dutch Ministry of Defence website at http://www.mindef.nl/english/index.htm has no budgetary information. One interesting document on the site is the Framework Memorandum for the 2000 Defence White Paper. However, as a starting point for broader discussion leading to the publication of a Defence White Paper outlining Dutch defence priorities for the coming decade, it has no specific budget information. It only gives a broad picture of the financial constraints upon the national military in a chapter entitled Financial Aspects. Thus, we learn that the Ministry of Defence is facing cutbacks in its yearly budget, that it plans on investing some more money and that it hopes to finance these investments through restructuring of its armed forces.

We learn more about the defence budget cutbacks on the Ministry of Finance website at http://www.minfin.nl/Minfinuk.asp?blnNews_UK=-1. In a document entitled The Abridged Version of the Budget Memorandum 2000, to be found through the Budget link, the Dutch Ministry of Finance notes that defence expenditures for 1999 and 2000 reach some 13.8 billion Dutch guilders (NLG), or some 6.26 billion euros. These expenditures have thus been cut by NLG 0.4 billion.

\section{United States}

The defence page for the U.S. Department of Defense can be found at http://www.defenselink.mil. Although the actual budget does not appear to be available through Defenselink, one section of the site does explore DoD's Slice of the $\$$. Within this section, several issues are addressed, including: breakdown of the budget, the budget by component, DoD estimate payroll, contracts, and grants by state/area, procurement dollars, top defence contractors, and a research development, test, and evaluation program. Another document available through the Internet is the President Clinton's Fiscal Year Defense Budget.

\section{Conclusions}

The Internet appears to be a powerful tool for researching military budgetary figures. Although the availability varies from country to country, a fair bit of relevant information can be gathered to answer immediate questions related to military budgets. There are drawbacks however to using the Internet for this type of research. First, not everybody has the means to put information on the Internet for public consumption. Thus, one might erroneously conclude that a country has not made its budget public, when in fact it simply has not been made available on the Internet. Likewise, the technology used by the person looking into the information can also be an obstacle to efficient access to the information, which has been made available on 
the Internet. Using the facilities made available to us at the Bulgarian Ministry of Defence, we noticed for example that certain files were difficult, if not impossible, to download. Secondly, in terms of language, not all Ministries of Defence translate their entire sites into English. Often only excerpts are made available. Thirdly, reports with complete figures and details are rare. Instead, excerpts are most often the only information available, and comparing defence budget excerpts from one country with those of another does not make for comprehensive and convincing research.

The research also provides further conclusions. There does not appear to be a NATO standard for the way in which member countries should present military budget information. This does not give NATO-aspiring countries any sort of indication of what military budget transparency through the Internet should consist of or how it should be presented. Although it would appear obvious that the percentage of the GDP is a fairly basic starting point, some NATO member countries have not made this information available on their Internet sites. Incidentally, there are a number of non-NATO countries that have made this information very readily available, in the English language.

Thus, as a preliminary step into the research of military budget transparency issues, Internet research provides a constructive and clear framework. It should always be kept in mind though, that there are some constraints to this type of research, which can directly affect the findings and resulting comparisons. Full defence budget transparency that can lead to better civil and international control, and ultimately to a higher degree of regional security, is not yet a fact of life when it comes to the information made available on the Internet. Consequently, the Internet, if not used properly, could become not a tool for democracy, but on the contrary a hindrance to the democratic processes where information remains incomplete and possibly incomprehensive.

There is a danger that full reliance on the Internet to provide the people with information could put the citizen at risk of losing ground against ever more technocratic and complex state institutions. When analysing democracy in America, Alexis de Tocqueville observed that the system was successful because of its federal nature and the existence of pressure groups, in other words, because of the existence of a formal circuit of checks and balances of the central governmental institutions. According to the French political philosopher, the individual alone is helpless against the state.

Drawing a parallel with the feudal societies in Europe, where the aristocracy exercised control over the sovereign monarch, de Tocqueville was worried about the anti-democratic effects of the French Revolution. Without the powerful aristocracy to curb its power, he thought the new French republican state would become an ever 
more authoritarian institution imposing its will on the lonely and alienated citizen. Likewise, a modern society without civil organizations to defend the particular interest of the citizens would tend to be authoritarian, as the state would be freed of all social control. As a matter of fact, these civil organizations tend to have more resources (time, money and expertise) than the individual citizen to keep an eye on and analyse public policy.

As the democratic attributes of the Internet seem to be growing every day, the fundamentals of de Tocqueville's conclusions appear to be ever so pertinent. If the citizen is abandoned in the global village, forced to surf the Net by himself and without the guidance and expertise of civil organizations, he will find himself isolated when facing governmental institutions, information and decisions.

Thus it is important, in the name of the democratic process, to come to a balanced conclusion of both the advantages of the Internet as a tool for rendering information more available and the expertise of national or international governmental or nongovernmental organizations as interpreters of this information. With respect to the defence budget transparency through the Internet and its effects on regional security, governments appear to need expert technical help in order to provide the relevant budgetary information.

Furthermore, they seem to need guidelines as to what should be made available and where. Such guidelines, if internationally determined, will put the different governments at ease when providing their information, knowing that the others will be doing it as well. The creation of some kind of regional institution concerned with setting the guidelines and gathering and interpreting the information appears thus to be a prerequisite to achieving sound defence budget transparency through the Internet in SEE.

Noticing that "every developing region has some form of regional institution that could serve as a collection point and repository for defence spending information" and that "each developing region has one or more core states which have developed, to some degree, greater transparency in defence budget matters", Paul George considers that "a greater effort should be put into developing regional, or subregional, data bases on defence spending, [as] this effort should be undertaken at the regional level, using local resources as much as possible." "A smaller, localized, system of reporting on defence spending would provide regional states with a larger stake in the security outcome of the process and would encourage greater reporting compliance." 9 


\section{Appendix: A List of the Internet Addresses Mentioned in the Article}

\section{Bulgaria}

- Government - http://www.government.bg

- Ministry of Defence - http://www.md.government.bg

- $\quad$ Ministry of Finance - http://www.minfin.government.bg/www/index.html

\section{Canada}

- Department of National Defence - http://www.dnd.ca

- Department of National Defence: Defence Policy http://www.dnd.ca/admpol/docs_e.htm

- Ministry of Finance - http://www.fin.gc.ca

\section{Croatia}

- Government - http://www.vlada.hr/english/contents.html

- Ministry of Defence - http://tomislav.morh.tel.hr

- Ministry of Finance - http://www.mfin.hr/index_eng.htm

\section{Czech Republic}

- Government - http://www.vlada.cz/1250/eng/vlade/vlada_clenove.htm

- Ministry of Defence - http://www.army.cz/english/index.htm

- $\quad$ Ministry of Finance - http://www.mfcr.cz/scripts/hpe/default.asp

\section{Estonia}

- Ministry of Defence - http://www.mod.gov.ee

\section{Finland}

- Ministry of Defence - http://www.vn.fi

- Ministry of Finance - http://www.vn.fi/vn/vm/english/mof.htm

\section{Former Yugoslav Republic of Macedonia}

- Ministry of Defence - http://www.morm.gov.mk/eng/mo_e.htm

\section{France}

- $\quad$ Ministry of Defence - http://www.defense.gouv.fr 
- $\quad$ Ministry of Defence: Defence Expenditure Charts http://www.defense.gouv.fr/sga/budget/indexb.htm

\section{Germany}

- $\quad$ Ministry of Defence - http://www.bundeswehr.de

\section{Great Britain}

- Ministry of Defence - http://www.mod.uk

- Her Majesty's Treasury - http://www.hm-treasury.gov.uk

\section{Greece}

- Prime Minister's Office - http://www.primeminister.gr/index_en.htm

- Ministry of Defence - http://www.mod.gr/english/index.htm

- Ministry of Finance: General Accounting Office - http://www.mof_glk.gr

- Ministry of Finance: General Secretary of Information Systems http://www.gsis.gov.gr

\section{Hungary}

- Government - http://www.meh.hu/default.htm

- $\quad$ Ministry of Defence - http://www.h-m.hu/mod

\section{Italy}

- Government - http://www.palazzochigi.it

- Ministry of Defence - http://www.difesa.it

- Ministry of Finance - http://www.finanze.it

\section{Latvia}

- $\quad$ Ministry of Defence - http://www.mod.lv

- Ministry of Finance - http://www.fm.gov.lv/05sak/05sak_a.htm

\section{Lithuania}

- Ministry of Defence - http://www.kam.lt/english

- Ministry of Finance - http://www.finmin.lt/fmhomeen.htm 


\section{Moldova}

- $\quad$ Ministry of Defence -

http://www.moldova.md/ro/government/oll/DEFENSE/index.htm

- Ministry of Finance - http://www.moldova.md/en/government/index.html

\section{The Netherlands}

- $\quad$ Ministry of Defence - http://www.mindef.nl/english/index.htm

- Ministry of Finance - http://www.minfin.nl/Minfinuk.asp?blnNews_UK=-1

\section{Poland}

- $\quad$ Ministry of Defence - http://www.wp.mil.pl/glowna.html

- Ministry of Finance - http://www.mofnet.gov.pl/ministry/index.shtml

\section{Romania}

- Ministry of Defence - http://www.mil.logicnet.ro/old/0.htm

- Ministry of Finance - http://www.mfinante.ro/menua.htm

\section{Russia}

- Ministry of Finance - http://www.minfin.ru

- Economic Expert Group - http://www.eeg.ru

\section{Slovakia}

- Ministry of Defence - http://www.mod.gov.sk

- Ministry of Finance - http://www.finance.gov.sk

\section{Slovenia}

- $\quad$ Ministry of Defence - http://www.mo-rs.si/mors/eng/index.htm

\section{Turkey}

- $\quad$ Ministry of Defence - http://www.msb.gov.tr/bakan/bakan.htm

- $\quad$ Armed Forces - http://www.tsk.mil.tr

- $\quad$ Ministry of Finance - http://www.maliye.gov.tr

\section{The United States}

- $\quad$ Ministry of Defence - http://www.defenselink.mil 


\section{Ukraine}

- $\quad$ Ministry of Defence - http://www.dod.niss.gov.ua

- Ministry of Finance - http://www.minfin.gov.ua

\section{References:}

1. Joseph Stiglitz, On Liberty, the Right to Know, and Public Discourse: The Role of Transparency in Public Life, Oxford Amnesty Lecture (Oxford, U.K., 27 January 1999). Available also at http://www.worldbank.org/html/extdr/extme/jssp012799.htm.

2. Stiglitz, On Liberty, the Right to Know.

3. Todor Tagarev gives a comprehensive view of the programming cycle presently being introduced in the Bulgarian Ministry of Defence and its implications for civil-military relations in Todor Tagarev, "Defence Programming - Crucial Link in Civilian Control," to appear in Balkan Security and Defence Policy Modernisation (Sofia: University Publishing Stopanstvo, 2000). The paper was presented at an international seminar under the same title in Ribaritsa, Bulgaria, on May 24-27, 2000.

4. Tagarev, "Defence Programming."

5. Tilcho K. Ivanov, Confidence and Security in the Balkans: The Role of Transparency in Defence Budgeting (Sofia: Institute for Security and International Studies, Research Report 6, 1996). Available in full text at http://www.isn.ethz.ch/isis/Publications/. The author emphasises that irrational thinking is an important determinant of Balkan security today: "The irrational factors are connected with the human feelings, fears, hopes and perceptions. They have a predominant psycho-emotional character. Ethnic, religious, socio-cultural and other motives induce the people to act in one or other way. War is born by fear. It is difficult to describe the mechanisms of this relationship, but it is out of doubt that the irrational factors are decisive for the Balkan security."

6. Paul George, "Defence Expenditures in the 1990s: Budget and Fiscal Policy Issues for Developing Countries", International Conference on Converting Defence Resources to Human Development, Bonn, 9-11 November 1997. Available at http://www.bicc.de /general/events/devcon/george.html. 
7. Ivanov, Confidence and Security in the Balkans. Tilcho Ivanov writes: "[A]s the budget is a message to our neighbours about the defence goals and the ways to achieve them [and] if the welfare of the citizens is a government concern, then the resources used for security matters are an element of international relations and they influence directly the confidence and the good neighbourly relations between states." Furthermore, he writes, "acceptance of the military planning standards inherent to contemporary society is a means for restraining sudden changes of intentions and for giving clear signals about the forming of threats to security."

8. George, "Defence Expenditures in the 1990s."

9. George, "Defence Expenditures in the 1990s."

KATE STARKEY holds a Bachelor's degree in North American Studies from McGill University, Montreal, Canada. E-mail: katestarkey@ hotmail.com.

ANDRI VAN MENS holds a Bachelor's degree in Political Science from the University of Montreal and is presently completing a Master's degree in International Relations at the University of Amsterdam. E-mail: asvmens@hotmail.com.

The authors wrote this article as interns at the Ministry of Defence of the Republic of Bulgaria during which time they helped organize an international seminar on Promotion of Transparency and Democratic Decision Making in the Formation of SEE States Military Budgets in Sofia (Bulgaria) on 6-7 June 2000. Their internship was organized by the Canadian-Bulgaria Business Council and financed through the Canadian Ministry of Human Resources Development Canada. 